\title{
Dry and Wet Wear Rate Determination of Steel and Kovar Alloys
}

\author{
Hadia Kadhim Judran* \\ Electromechanical Engineering Department, University of Technology, Baghdad, Iraq
}

\begin{tabular}{ll}
\hline \multicolumn{1}{c}{ Articles Information } & \multicolumn{1}{c}{ Abstract } \\
\hline Received: & Two types of alloy (Steel and Kovar) were prepared and machined as half ring. \\
12.01.2011 & Wear testing system was used to determine the wear rate of specimens without \\
Accepted: & any lubrication, and after modified wear testing system which was used to test \\
15.06.2011 & the specimen under lubricant condition. The wear rate was determined by using \\
Published: & weighing method and then calculated. The results shows the values of wear rate \\
01.12 .2020 & of kovar specimens are higher than the values of wear rate for steel specimens \\
Keywords: & in both two cases with and without lubrication. The result of wear rates were \\
Adhesive wear & plotted as function of sliding time at a fixed normal load. \\
Wear rate & \\
Kovar & \\
Steel & \\
Lubricant &
\end{tabular}

DOI: 10.22401/ANJS.23.4.07

*Corresponding author: hadia_kadhim2010@yahoo.com

\section{Introduction}

Damage by wear phenomena leads to economic losses across the many branches of industry and although wear itself may not alone limit the life of, and investment in, a place of plant, it is certainly the cause of large expenditure on maintenance and remedial repairs $[1,2]$. The subject of wear is complicated by a confusion of nomenclature and the lack of good definition of the different types of wear found in engineering situations [3]. The major difficulty in the field of wear is the inability to predict the progress of wear from fundamental material properties. This is part to the complexity of most wear environment refers to the complete set as factors that describe a given interface. The comparison between the dry wear rate (without lubricant) and the wet wear rate (with lubricant), shows the influence of lubricant to minimize the wear damage to increase the life work for the contact mechanical parts [4-6].

\section{Theoretical Part \\ 2.1 Wear principles}

Wear is defined as the loss of material from interface of two bodies when these bodies move with respect to each other under load. It results in reducing the service ability of the body [6, 7]. Kargelskii [8] defines wear as the destruction of material produced as a result of repeated disturbances of the frictional bond. To achieve the ultimate goal of minimizing wear contributors have proposed several methods to classify wear either according to its severity or according to the basic mechanism that contributes to it [9]. When two solid material are placed in contact some regions on their surfaces will be very close together, which represents the tips of the major asperities of the surfaces. These regions of atom-to-atom contact which occur between these surfaces are referred to as "junctions" (which is local welding of the asperities due to plastic flow), these junctions will cause friction, the sum of the area of all junctions constitute the area of contact [10].

\subsection{Adhesive wear}

To explain the adhesive wear process, it is necessary to have an understanding of the real contact which occurs between two solid surfaces, any smooth surface is, on the microscopic scale, rough, and consists of a series of jagged peaks and valleys [11]. The common type of adhesive wear occurs when two smooth surfaces slide against each other; and the pressure between the contacting asperities is high enough to cause local plastic deformation and adhesion. Adhesive wear represent $15 \%$ of industrial wear problems [12]. This type of wear arises from the strong adhesive forces setup whenever atoms come into contact. In this wear process metal transfer from on surface (usually the softer) to the other surface (comparatively harder) takes place, which eventually results in the formation of loose fragments.

\subsection{Wear rates calculations}

Weighing method is the simplest way of detecting wear. The specimen is weighed before and after running, and the weight loss calculated to get the wear rate according to the following equation $[13,14]$.

Wear rate $=\mathrm{W} / \pi \mathrm{DMT}$

Where:

$\mathrm{W}$ : weight loss (gm). 


\section{Al-Nahrain Journal of Science}

ANJS, Vol.23 (4), December, 2020, pp. 40-43

\author{
D: sliding distance $(\mathrm{cm})$. \\ M: sliding speed (r. p. m). \\ $\mathrm{T}$ : running time $(\mathrm{min})$. \\ The accuracy of this method depends upon the \\ accuracy of the sensitive balance.
}

\section{Experimental Part}

The wear experiments were designed to facilitate the application of different normal loads between two contacting surfaces at different sliding times. These experiments were conducted according to ASTM G83-83 [15] at fixed sliding speed (S.S $=750 \mathrm{rpm})$. Wear rates were calculated by weight loss method. In this method the specimen was weighed before $\left(\mathrm{W}_{1}\right)$ and after $\left(\mathrm{W}_{2}\right)$ each test to determine the weight loss $\left(\mathrm{W}_{1}-\mathrm{W}_{2}\right)$ wear rate was calculated according to the equation (1).

\subsection{Samples preparation}

Two types of alloys namely steel and kovar were prepared. These alloys were machined as half rings, and the main properties of alloys were tabulated in Table 1. Firstly each samples were polished and cleaned by using acetone and when the process go over then the samples were cleaned from oils before weighed for testing requirement.

Table 1. Properties of the samples used in the work.

\begin{tabular}{|c|c|c|c|}
\hline Alloys & Composition \% & Density & Supplier \\
\hline Steel & C: 0.18 & $7.84 \mathrm{~g} / \mathrm{cm}^{3}[19]$ & BDH company \\
& S: 0.05 & & \\
& Si: trace & & \\
& The remainder is Fe & & Westing house \\
& Fe: 53 & $8.36 \mathrm{~g} / \mathrm{cm}^{3}$ & (USA Product) \\
\hline Kovar & Co: 18 & & \\
\hline
\end{tabular}

\subsection{Wear test}

The alloys (steel and kovar) were tested under different normal loads of $(5,10,15 \mathrm{~N})$ and different sliding times of (10, 20, 30, 40, 50 minutes). These conditions were applied in dry and wet wear experiments. The samples were conducted to wear system using oil type power 100 high duties as lubricant in wet wear experiments, while the experiments of dry wear were conducted without any lubricant.

\section{Results and Discussion}

Tables 2 and 3 represent the weight losses of steel and kovar alloys with and without lubricant respectively at different sliding time under different normal loads 5,10 , and $15 \mathrm{~N}$. In all specimens the weight loss increased gradually under different circumstances. This behavior involved two states; wet and dry wear, but in the dry wear case the values of weight loss is higher than that of wet wear case. In the beginning of the sliding, the removal of some materials from the specimens was due to wear, arises when junctions weld together become broken by relative motion, this agrees with references [16-18]. The action of lubricant minimize the friction force by separate the mating surfaces, and to work hardening of the surface after 30 minutes.

Table 2. Steel alloy weight loss (gm) results from wet and dry wear.

\begin{tabular}{|c|c|c|c|}
\hline \multirow{2}{*}{$\begin{array}{c}\text { Loads } \\
(\mathbf{N})\end{array}$} & \multirow{2}{*}{$\begin{array}{l}\text { Sliding time } \\
\text { (min.) }\end{array}$} & \multicolumn{2}{|c|}{ Weight loss $(\mathrm{gm}) \times 10^{-3}$} \\
\hline & & Wet processes & Dry processes \\
\hline \multirow{5}{*}{5} & 10 & 0.22 & 0.51 \\
\hline & 20 & 0.46 & 1.1 \\
\hline & 30 & 0.72 & 1.82 \\
\hline & 40 & 0.97 & 2.60 \\
\hline & 50 & 1.27 & 3.37 \\
\hline \multirow{5}{*}{10} & 10 & 0.27 & 0.6 \\
\hline & 20 & 0.56 & 1.22 \\
\hline & 30 & 0.87 & 2.10 \\
\hline & 40 & 1.29 & 2.82 \\
\hline & 50 & 1.62 & 3.54 \\
\hline \multirow{5}{*}{15} & 10 & 0.29 & 0.67 \\
\hline & 20 & 0.59 & 1.39 \\
\hline & 30 & 0.92 & 2.20 \\
\hline & 40 & 1.33 & 2.97 \\
\hline & 50 & 1.69 & 3.80 \\
\hline
\end{tabular}




\section{Al-Nahrain Journal of Science}

ANJS, Vol.23 (4), December, 2020, pp. 40-43

Table 3. kovar alloy weight loss (gm) results from wet and dry wear.

\begin{tabular}{|c|c|c|c|}
\hline \multirow[b]{2}{*}{$\begin{array}{l}\text { Loads } \\
\text { (N) }\end{array}$} & \multirow[b]{2}{*}{$\begin{array}{c}\text { Sliding } \\
\text { time (min.) }\end{array}$} & \multicolumn{2}{|c|}{ Weight loss $(\mathrm{gm}) \times 10^{-3}$} \\
\hline & & $\begin{array}{c}\text { Wet } \\
\text { processes }\end{array}$ & $\begin{array}{c}\text { Dry } \\
\text { processes }\end{array}$ \\
\hline \multirow{5}{*}{5} & 10 & 0.87 & 1.60 \\
\hline & 20 & 1.83 & 3.40 \\
\hline & 30 & 2.85 & 5.35 \\
\hline & 40 & 3.86 & 7.36 \\
\hline & 50 & 4.85 & 9.22 \\
\hline \multirow{5}{*}{10} & 10 & 1.10 & 2.45 \\
\hline & 20 & 2.50 & 5.00 \\
\hline & 30 & 3.80 & 7.81 \\
\hline & 40 & 5.10 & 10.50 \\
\hline & 50 & 6.38 & 13.18 \\
\hline \multirow{5}{*}{15} & 10 & 1.46 & 2.74 \\
\hline & 20 & 3.15 & 6.20 \\
\hline & 30 & 4.92 & 9.45 \\
\hline & 40 & 6.69 & 12.83 \\
\hline & 50 & 8.41 & 16.10 \\
\hline
\end{tabular}

At the same time we can notice the effects of normal loads on the values of weight loss, this due to increase of normal force and to increasing frictional force between contact parts. Table 3 shows that the weight loss from the kovar alloy (38 $\mp 3 \mathrm{HRC}$ ), the values of hardness represent strong indicator that the weight loss in kovar alloys is greater than in steel alloy. Figures 1, 2, and 3 represent the wear rates variation with sliding time at different normal loads for steel and kovar alloys in lubricant oil (wet wear) and without lubricant (dry wear). At the beginning of the sliding time the values of wear rates for all specimens under tests will be increase. The wear rate values are decrease after 30-minutes of sliding time, due to the separation of the junctions between the specimens and the parts of wear system by the lubricant film as well as the flattening of the specimens which will lead to stability in wear rate behavior with sliding time. While the results of dry tests shows high values of wear rate, this confirm that the wear rate can be reduce by using lubricant film but cannot disappear by using any lubricant.

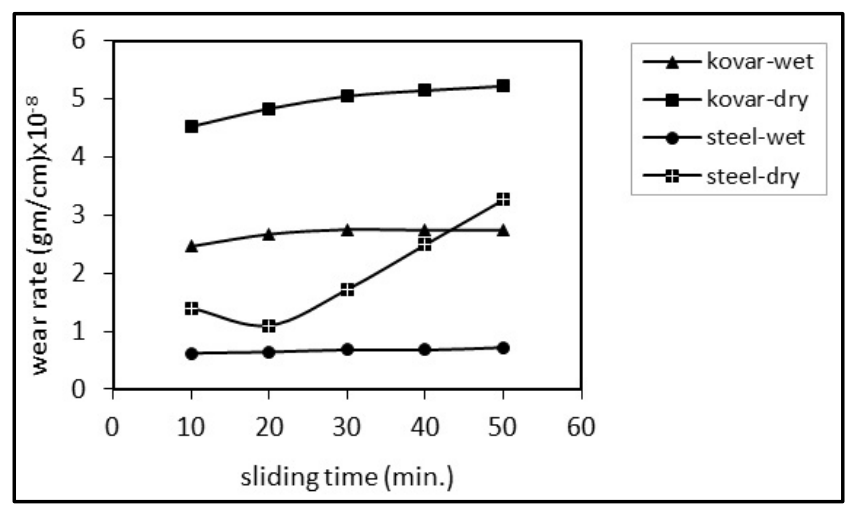

Figure 1. Wet and dry wear rate as a function of sliding time at loads of $5 \mathrm{~N}$.

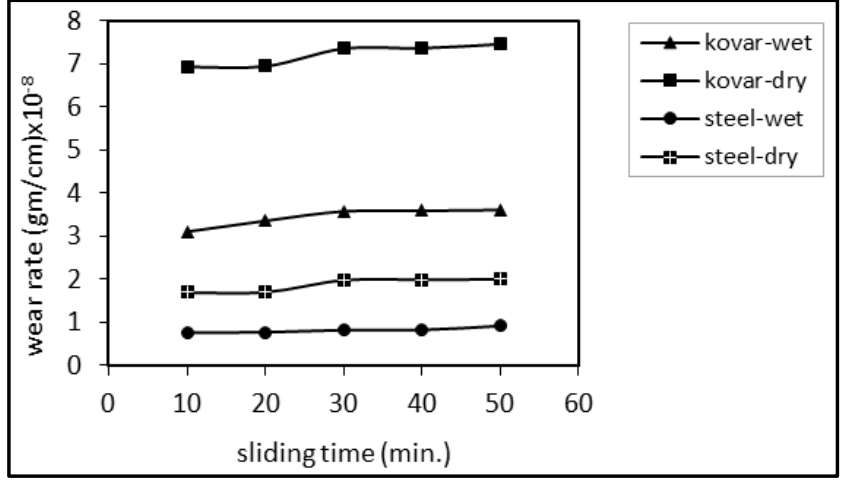

Figure 2. Wet and dry wear rate as a function of sliding time at loads of $10 \mathrm{~N}$.

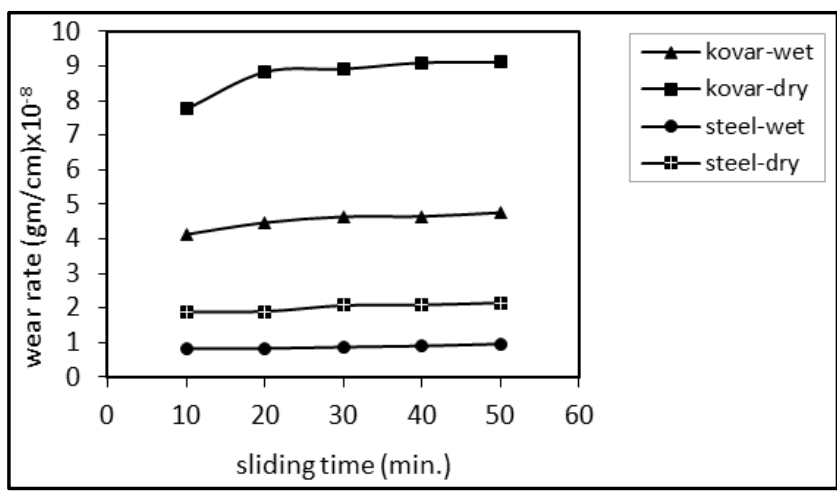

Figure 3. Wet and dry wear rate as a function of sliding time at loads of $15 \mathrm{~N}$.

Table 4 shown that the normal loads of $(5 \mathrm{~N})$ leads the wear rates will be increase rapidly while for higher loads (greater than $5 \mathrm{~N}$ ) the increase will be slight. This is may be due to an increase in stability of adhering lubricant films to specimen surface at high loads, and decreasing the friction force. For dry wear tests the same behavior, may be due to the properties of specimen surface. 


\section{Al-Nahrain Journal of Science}

ANJS, Vol.23 (4), December, 2020, pp. 40-43

Table 4. Wet and dry wear rate of kovar and steel under different conditions.

\begin{tabular}{|c|c|c|c|c|c|}
\hline $\begin{array}{l}\text { Loads } \\
(\mathbf{N})\end{array}$ & $\begin{array}{l}\text { Sliding time } \\
\quad \text { (min.) }\end{array}$ & $\begin{array}{c}\text { Kovar } \\
\text { wet wear rate } \\
(\mathrm{gm} / \mathrm{cm}) \times 10^{-8} \\
\end{array}$ & $\begin{array}{c}\text { Kovar } \\
\text { dry wear rate } \\
(\mathrm{gm} / \mathrm{cm}) \times \mathbf{1 0}^{-8} \\
\end{array}$ & $\begin{array}{c}\text { Steel } \\
\text { wet wear rate } \\
(\mathrm{gm} / \mathrm{cm}) \times 10^{-8}\end{array}$ & $\begin{array}{c}\text { Steel } \\
\text { dry wear rate } \\
(\mathrm{gm} / \mathrm{cm}) \times 10^{-8}\end{array}$ \\
\hline 5 & $\begin{array}{l}10 \\
30 \\
50\end{array}$ & $\begin{array}{l}2.460 \\
2.850 \\
2.740\end{array}$ & $\begin{array}{l}4.524 \\
5.048 \\
5.220\end{array}$ & $\begin{array}{l}0.622 \\
0.679 \\
0.719\end{array}$ & $\begin{array}{l}1.400 \\
1.717 \\
1.851\end{array}$ \\
\hline 10 & $\begin{array}{l}10 \\
30 \\
50 \\
\end{array}$ & $\begin{array}{l}3.110 \\
3.580 \\
3.612 \\
\end{array}$ & $\begin{array}{l}6.935 \\
7.360 \\
7.462 \\
\end{array}$ & $\begin{array}{l}0.764 \\
0.821 \\
0.917 \\
\end{array}$ & $\begin{array}{l}1.690 \\
1.980 \\
2.000 \\
\end{array}$ \\
\hline 15 & $\begin{array}{l}10 \\
30 \\
50\end{array}$ & $\begin{array}{l}4.130 \\
4.642 \\
4.760 \\
\end{array}$ & $\begin{array}{l}7.756 \\
8.917 \\
9.110 \\
\end{array}$ & $\begin{array}{l}0.822 \\
0.868 \\
0.957\end{array}$ & $\begin{array}{l}1.890 \\
2.075 \\
2.150\end{array}$ \\
\hline
\end{tabular}

\section{Conclusions}

1- It is clear from the present results that the conditions of increasing sliding time and normal loads will increase with weight loss and hence the wear rate for all specimens.

2- The weight loss of all steel alloy specimens is less than that of kovar alloy specimens. This behavior may be due to the hardness.

3- The dry wear rates values is higher than that of wet wear rates.

4- The steady state condition started at sliding time of 30 minutes and normal loads higher than $5 \mathrm{~N}$.

\section{References}

[1] V. H. Davies, and L. A. Bolton, "The mechanism of wear weld surfacing and hard facing", New York, 1980.

[2] G. Cumming, and I. G. Donald, "The determination of Iron in lubricating oils by X-ray fluorescence spectrometry", J. of wear an international. Australia, 57-66, 1985.

[3] A. R. Lansdown and A. L. Price, "Material resist wear", Pergham Press, Oxford, 1988.

[4] C. S. Yust, , "International metals review", Vol. 30, No. 3, 141-154, 1985.

[5] V. S. Kusknev, and A.V. Boyarniko, "Wear and friction", International J. of Computation and Applied Sciences, Vol. 19, No.4, 498-504, 1998.

[6] ASTM, , "Designation G77-83", Sec.3, Vol.2, 1998.

[7] S. L. Kakani and A. Kakani, "Material science", Newdelhi, 201-203, 2004.

[8] K. Kragelskii and W. Wahi, "Surfacing technology", Syrfacing J., Vol. 11, No. 1, 856-859, 1980.

[9] S. A. Astapchil and F. I. Pantelenko, "friction and wear", ISBN-13: 978-1-62708-141-2, Vol. 18, No. 2, 224-228, 1997.

[10] J. N. Sultan, "Sliding wear of porous surface under lubricated condition", M.Sc. Thesis, University of Technology, 1984.

[11] I. A. Alnammy, "Adhesive wears mechanism for brass alloy" Vol.15, 1996.
[12] T. S. Eyer, "Tribology international", 203-211, 1976.

[13] H. Czichos, "Tribology series", $1^{\text {st }}$ edition, Elsevier Scientific Publishing Company, 103-135, 1978.

[14] W. A. Glaseser, "Iron making and steel making", J. of metals, Vol.35, No.10, 50-55, 1983.

[15] ASTM designation G83-83, Vol. 3, No. 2, 1988.

[16] L. H. Vanvlack, Elements of materials science and engineering", ch.1, $7^{\text {th }}$ edition, Addison-Wisley publishing Co. New York, 2001.

[17] S. H. Abbas, "Effect of hardness on wear resistance of steel", M.Sc. Thesis, University of Technology, 2001.

[18] F. M. Rasheed, "an investigation into the dry sliding wears of some copper alloy", M.Sc. Thesis, Technology education department, University of Technology, 2000. 